\title{
Fotografias poderão dar testemunho do trauma de refugiados no Brasil?
}

\author{
Tânia Biazioli de Oliveira * \\ Polyana Stocco Muniz ** \\ Paulo César Endo ***
}

\begin{abstract}
A fotografia que dá testemunho do calamitoso e do condenável é muito criticada se parece "estética"... A foto [bela] dá sinais misturados.

Pare isto, ela exige. Mas também exclama:

Que espetáculo! (Susan Sontag).
\end{abstract}

Trata-se de um estudo sobre fotografias de refugiados e um possível diálogo com a literatura sobre trauma e testemunho ${ }^{1}$. Para isto, analisamos alguns folhetos da Cáritas Arquidiocesana de São Paulo, responsável pela acolhida aos refugiados na cidade. Centramos o foco nas fotografias ali expostas. Nosso objetivo era verificar a possibilidade desse material produzir um verdadeiro testemunho sobre a condição dos refugiados no Brasil. Nossa hipótese era que poderia haver uma dissonância entre o caráter estético das fotografias e a situação traumática vivida pelos refugiados.

Apesar de ser uma realidade pouco conhecida, existem 25,2 milhões ${ }^{2}$ de pessoas no mundo forçadas a se deslocar. Os países em desenvolvimento acolhem $4 / 5$ dos refugiados do mundo; $3 / 4$ dos refugiados permanece na sua região de origem, procurando proteção nos países vizinhos e $1 / 3$ dos refugiados residem em campos. Afegãos e iraquianos somam juntos quase a metade dos refugiados

\footnotetext{
* Psicóloga, Mestre em Psicologia Social pelo Instituto de Psicologia da USP.

**Psicóloga, Mestre em Psicologia Escolar e do Desenvolvimento Humano pelo Instituto de Psicologia da USP.

*** Psicanalista, Professor Doutor do Instituto de Psicologia da USP.
} 
do mundo (UNHCR, 2011). Atualmente, o Brasil abriga 4.401 refugiados, de 77 nacionalidades diferentes, sendo que $64,17 \%$ vieram do continente africano. Os angolanos formam o maior grupo de refugiados (38,37\%), seguido dos colombianos $(14,27 \%)$ e congoleses (10,31\%) (CONARE, 2011).

Partimos de algumas questões trazidas por Shoshana Felman (2000) que trata o testemunho como a modalidade crucial de nossa relação com os acontecimentos do nosso tempo, marcado por grandes catástrofes. Felman pensa o testemunho como o meio de transmissão do trauma, possibilitando (ou não) a irrupção de uma experiência de crise que implicaria na produção de alguma inflexão sobre o real, assim sendo, o testemunho poderia possibilitar algum esclarecimento sobre a situação de horror a que estamos expostos em nosso tempo. Theodor Adorno (2003) entende o testemunho como um modo de evitar a repetição de uma catástrofe. Testemunhar uma dor passa por uma designação própria, visando não somente o alívio da mesma, mas também a uma dimensão ética que perpassa a possibilidade de comunicar aos outros sobre uma catástrofe e assim possibilitar sua não perpetuação.

Ao tomarmos contato com estes textos que versam sobre a problemática do trauma, do testemunho e de suas consequências, tanto psíquicas quanto sociológicas, nos intrigamos justamente com a interface entre a estética e 0 horror: como entender as fotografias que carregam traços do trauma, na sua relação com a potência ética do despertar traumático? É imprescindível pensar sobre a relação entre este desígnio ético do testemunho e a dimensão estética da fotografia enquanto obra de arte. Poderá o trauma dos refugiados penetrar nessas fotografias, e poderão essas fotografias lançar luz sobre o mistério deste trauma?

Há um hiato entre quem sofreu o trauma e quem somente toma contato com alguma fotografia. Em que medida este produto consegue transmitir ou trazer à tona o horror - não no sentido de nos identificarmos com ele ou termos uma relação fria, mas sim nos aproximarmos dele e até termos uma experiência de crise?

\section{Trauma e Testemunho}

No texto "Educação e crise ou as vicissitudes do ensinar", Shoshana Felman (2000) ressalta que com o trauma da história contemporânea - Segunda Guerra Mundial, Holocausto, bomba nuclear e outras atrocidades da guerra - o testemunho se tornou uma modalidade crucial de nossa relação com os acontecimentos de nosso tempo. Já foi sugerido, até mesmo, que o testemunho é o modo literário ou discursivo por excelência de nossa época, que pode ser definida, portanto, como a era do testemunho.

Quem faz o testemunho passa por uma estranha designação da qual não pode se aliviar por meio de qualquer delegação, substituição ou representação. Deste modo, encerra uma função: o sujeito tem de aguentar a solidão de uma responsabilidade e suportar a responsabilidade desta solidão, pois somente ele pode testemunhar seu fardo. 
Ao mesmo tempo essa designação solitária e intransferível é paradoxal, pois necessita do outro. A fala testemunhal transcende a própria testemunha ao se dirigir a outros, transgredindo os limites daquela posição isolada a fim de interceder para além de si mesma.

O testemunho parece ser composto por pequenas partes de memória há pouco oprimidas e que ainda não tinham se assentado como compreensão ou lembranças, e por atos "[...] que não podem ser construídos como saber nem assimilados à plena cognição, eventos em excesso em relação aos nossos quadros referenciais" (FELMAN, 2000, p. 18). Por isso, sua linguagem está em processo, ela possui a si mesma como não conclusiva, como não conclusão sobre qualquer veredicto. Testemunhar é realizar um ato de fala.

Como um ato de fala performático, o testemunho volta-se para aquilo que, na história, é ação que excede qualquer significado substancializado, para o que, no acontecer, é impacto que explode dinamicamente qualquer reificação conceitual e delimitação constativa (FELMAN, 2000, p. 18).

O verdadeiro testemunho é aquele que proporciona a crise, um testemunhar que possibilite o novo, a não repetição, que nos surpreenda, nos faça repensar referências e assim nos releve a verdade do trauma. Nas palavras de Felman (2000):

\footnotetext{
[...] testemunhar algo que possa ser surpreendente e cognitivamente dissonante. A surpresa implica a crise. 0 testemunho não é autêntico sem essa crise, que tem de, precisamente, quebrar e reavaliar categorias e pontos de referência precedentes (p. 68).
}

Porém, não acreditamos, como Felman, que a verdade do trauma seja algo a ser abarcado pela cognição, eficiente em integrar seus aspectos dissonantes. $O$ trauma trata daquilo que homens sofreram no próprio corpo imposto por outros homens. E isto inspira a indignação. É a aniquilação do corpo humano em sua corporeidade originária, indefesa e indeterminada. $O$ verdadeiro testemunho precisa acolher esse sofrimento sem palavras - a vergonha e o pudor das vítimas - que desarticula a vontade de sentido da arte e da reflexão. Pois abarca a transmissão do indizível, do irrepresentável - a morte sem sentido ${ }^{3}$.

Sobre a relação entre o testemunho - como ato de fala performático e que assume, em nosso tempo, o modo literário ou discursivo por excelência e o horror - ação que na história excede qualquer significado substanciado como pensar o papel da obra de arte? Ou ainda, entre o horror e a estética, cabe perguntar de que maneira o trauma da história incide sobre o testemunho enquanto obra de arte: como a arte pode existir em meio à barbárie? Felman traz para esse debate a consideração de Theodor Adorno sobre a necessidade de desestetizar a arte, enunciado em seu dito famoso: "Depois de Auschwitz, não é mais possível escrever poemas" (ADORNO apud FELMAN, p. 46). 
Adorno (2003), em "Educação após Auschwitz", critica o princípio estético da estilização, pois ao transfigurar o horror de nosso mundo em algo apreciável incorre em dois erros questionáveis: dá um sentido mais nobre a um destino impensável e algo do horror, próprio ao objeto, lhe é extirpado.

O perigo de que tudo aconteça de novo [a repetição de Auschwitz] está em que não se admite o contato com a questão, rejeitando até mesmo quem a menciona, como se, ao fazê-lo sem rodeios, este se tornasse o responsável e não os verdadeiros culpados (p.125).

A estilização, o lirismo, a poetização e o virtuosismo negam aquilo que querem representar, subtraindo-se ao confronto com o horror. Portanto, a arte hoje se quiser ser verdade, precisa ser contra si mesma, já que a busca pela beleza e pela nobreza humana tornaram-se uma injustiça frente ao sofrimento das vítimas.

No entanto, paradoxalmente, é apenas a arte que poderá satisfazer a tarefa do pensamento contemporâneo de postular sem palavras aquilo que foi barrado para a política e satisfazer as exigências do sofrimento, escapando à traição cultural da história e das vítimas.

Restou à obra de arte a tarefa de testemunhar sobre o horror, sem trair-se a si mesma; sem, portanto, negar a própria dor que quer representar, fazendo uma resistência criativa e autocrítica ao veredicto de que, desde então, é um ato de barbárie ser virtuosa.

Apesar de a arte não mudar os pressupostos objetivos, isto é, sociais e políticos que engendram os acontecimentos, rejeitar qualquer lembrança ao trauma, ou seja, contrapor-se ao testemunho, tem em si algo de regressivo. Afinal, é por meio da arte enquanto testemunho que há alguma possibilidade de negar a repetição do horror.

Portanto, Adorno pensa os trabalhos artísticos, após Auschwitz, enquanto meios de se conhecer e refletir sobre o passado imerso no horror e no trauma a fim de evitar sua repetição, sem transformar o horror em algo pleno de sentido pelo princípio estético da estilização.

Auschwitz, como representante do sofrimento intolerável, provocado pelo mal humano, não deve ser encarado com uma ética da compaixão pelo sofrimento alheio - que aceita esse sofrimento - mas sim com uma ética da resistência que critica e denuncia esse sofrimento ${ }^{4}$. Terão as fotografias compaixão pelo sofrimento dos refugiados, sendo complacentes com eles e buscando reconfortálos? Ou, ao invés da condescendência e da aceitação frente ao acontecido, serão as fotografias resistentes, criticando e denunciando esse sofrimento?

\section{A Cáritas Arquidiocesana de São Paulo e o Refúgio}

Através da Cáritas Arquidiocesana de São Paulo - organismo da Igreja Católica, representante do Alto Comissariado das Nações Unidas para Refugiados 
(ACNUR) e do Governo Federal, por meio do Comitê Nacional para os Refugiados (CONARE) e da Secretaria Especial de Direitos Humanos da Presidência da República (SEDH/PR) - os solicitantes de refúgio e refugiados recebem proteção jurídica, assistência e integração psicossocial na nossa cidade. No Centro de Acolhida de Refugiados, eles são atendidos por uma equipe multiprofissional, formada por advogados, assistentes sociais, um psiquiatra e uma psicóloga, em parceria com outras instituições. $\mathrm{O}$ foco do trabalho é garantir a proteção jurídica a partir da solicitação de refúgio; bem como oferecer assistência a necessidades básicas de saúde, alimentação e moradia; além de facilitar a integração na cidade por meio do acesso à educação e ao trabalho, através de encaminhamentos para cursos de língua portuguesa, cursos profissionalizantes, revalidação dos documentos escolares e agências de busca de emprego (OLIVEIRA, 2011, p. 40-44).

Ao analisar os folhetos distribuídos pela instituição, podemos perceber um vínculo maior da Cáritas de São Paulo ora com a Igreja Católica ora com o ACNUR. Desta forma, o refúgio pode ser compreendido por uma perspectiva religiosa ou do direito internacional.

Num dos folhetos, a ligação da Cáritas de São Paulo com a Igreja Católica destaca uma perspectiva religiosa do refúgio. Assim, a história atual do refugiado se confunde com a história antiga da humanidade. "A triste história de multidões obrigadas a sair de sua pátria é antiga quanto à história da humanidade." Esta perspectiva cristã não permite cortes no tempo, igualando o hoje ao ontem. Assim, o drama do refugiado nada deve à história dos homens. "Acolher o refugiado é semear a paz entre os povos." "Afinal, é impossível se omitir diante de tanto sofrimento de pessoas, gente como nós, filhos do mesmo Pai." "Ninguém tem o poder de resolver todos os problemas do mundo. Mas todos, temos o dever de contribuir para que a humanidade tenha mais paz e felicidade." Se o viés religioso, por um lado, tem um caráter a-histórico, por outro, não se omite em agir para acolher o refugiado.

É possível encontrar em todo e qualquer folheto um destaque para a ligação da Cáritas de São Paulo com o ACNUR. Então, os refugiados são igualados à definição do direito internacional, como aqueles que "tiveram que deixar seu país por temor de perseguição por causa de sua raça, religião, grupo social, nacionalidade, opinião política ou em função de grave e generalizada violação de direitos humanos". Os refugiados somente foram protegidos institucionalmente depois da criação do Alto Comissariado das Nações Unidas para Refugiados (ACNUR) em 1950. A proteção jurídica aos refugiados ocorreu após o surgimento da Convenção Relativa ao Estatuto dos Refugiados de 1951, que deu origem a outros instrumentos de proteção (ANDRADE, 1996). Já o Brasil regulamentou o refúgio pela Lei 9.474/97. Esta lei adotou tanto a definição clássica de refugiado - que se aplica às vítimas de perseguição (Convenção de 1951 e Protocolo de 1967) - quanto sua definição ampliada - que passa a incluir as vítimas de violação generalizada dos direitos humanos (Declaração de Cartagena de 1984) $)^{5}$. 


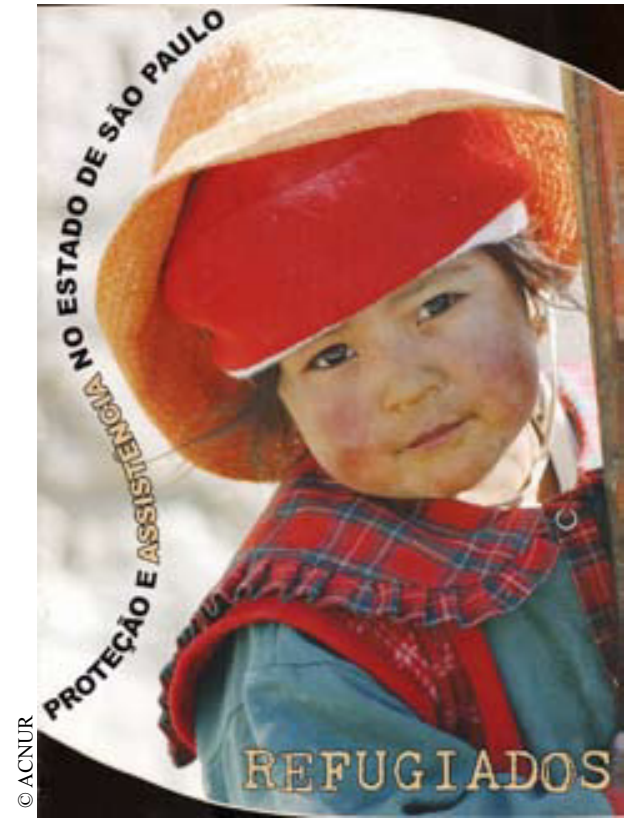

Figura 1

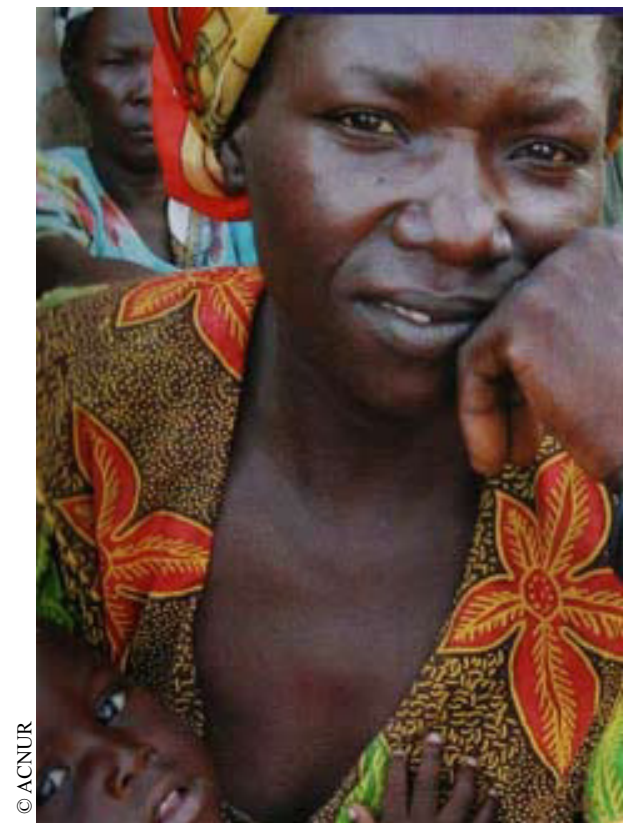

Figura 3

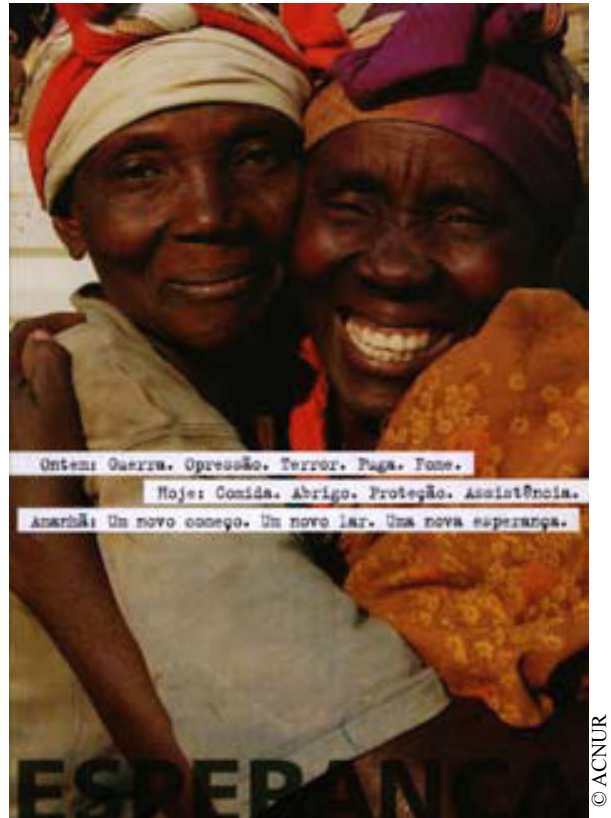

Figura 2

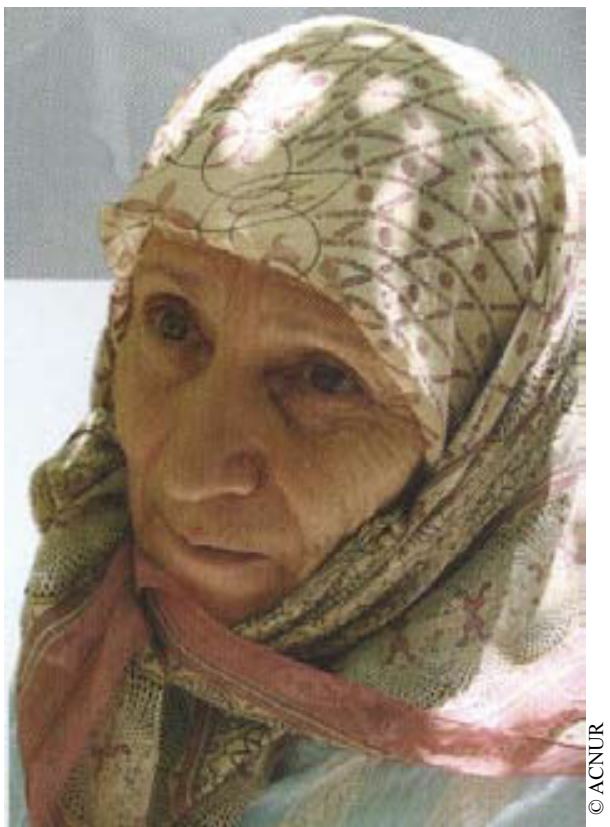

Figura 4 
A perspectiva que temos dos refugiados não decorre de povos obrigados a sair de sua pátria desde a antiga história religiosa da humanidade, tão pouco decorre de vítimas de perseguição ou vítimas de violação dos direitos humanos. Nossa perspectiva dos fluxos de refugiados ao redor do mundo decorre da crise do capitalismo global (KURZ, 2005). Em tempos de crise da sociedade do trabalho, um número cada vez maior de trabalhadores torna-se incapaz de vender a própria força de trabalho: os refugiados são rejeitados e discriminados, considerados supérfluos para o processo de valorização do capital. Os refugiados surgem das guerras civis sem fim, produzidas pela desertificação econômica nas zonas em colapso. Os poucos "oásis" de rentabilidade capitalista que restaram no mundo são protegidos contra os fluxos migratórios supérfluos. Muros são construídos e fronteiras são fechadas, afastando os refugiados.

\section{Fotografias de Refugiados}

Analisamos cinco folhetos ${ }^{6}$, produzidos pela Cáritas de São Paulo e pelo ACNUR e distribuídos ao público em caráter informativo, que recolhemos na instituição entre 2005 e 2008. Dirigimos nossa atenção para o conteúdo das fotografias, destacando os retratos dos refugiados de diferentes idades, ambos os sexos e diversas regiões do mundo, bem como os cenários do refúgio. Também nos chamou a atenção a forma das fotografias analisadas.

Quanto aos retratos de refugiados de diferentes idades, vemos uma grande quantidade de imagens de crianças (Fig. 1), enquanto os idosos (Fig. 2) aparecem em menor número. Os folhetos mostram uma predileção por fotografias de crianças sorridentes, que brincam entre si. Muitas apresentam um ar confiante e esperançoso. Pouquíssimas são aquelas que expõem um olhar desolado, diante da situação vivida. Uma única criança chorava para a câmera do fotógrafo.

A Folha de São Paulo lançou, em 2009, uma coleção com fotografias de Robert Capa, John Vink, Larry Towell e Sebastião Salgado sobre os refugiados. As crianças se destacam diante das lentes dos fotógrafos que documentaram o drama dos refugiados. Porém, a imagem das crianças que brincam não apaga a presença das outras crianças subnutridas e famintas. A fotografia do esquelético corpo da menina bôer Lizzie van Zyl, talvez tenha sido uma das primeiras imagens captadas dos refugiados. É um documento da Segunda Guerra Anglo-Bôer (1899-1902) na África do Sul, "quando o alto comando britânico reuniu as famílias dos

rebeldes em campos vigiados para Figura 5

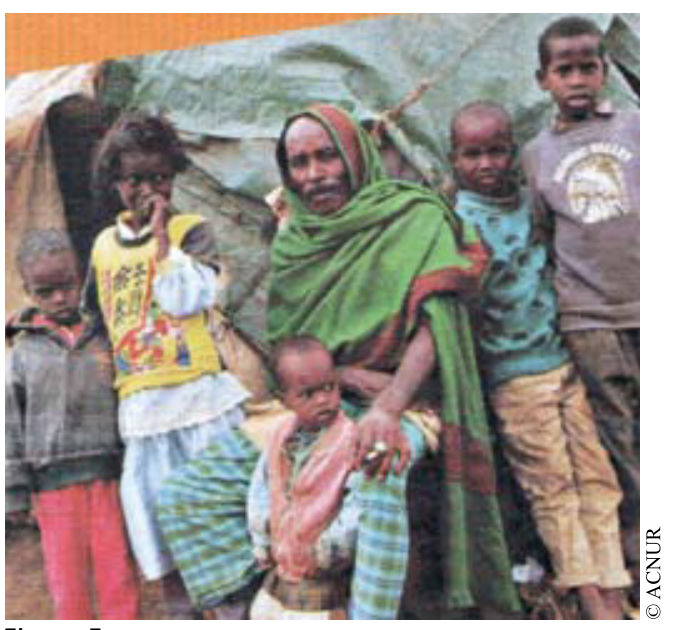


'evitar que fossem atacados'. Dos 27 mil bôeres que pereceram nesses campos, 22 mil eram crianças" (p. 3).

Quanto à representação dos refugiados de ambos os sexos, vemos muitas imagens de mulheres, principalmente mães de família (Fig. 3). As africanas carregam seus bebês amarrados junto ao corpo, enquanto os filhos pequenos as acompanham de perto. Já os homens são menos expostos. Geralmente, eles não aparecem no primeiro plano das fotografias. Temos um único retrato de um homem rodeado de crianças em frente de uma tenda num campo de refúgio. Provavelmente, é um pai de família.

Um folheto, produzido em comemoração ao Dia Mundial dos Refugiados (20 de junho), celebra "a tenacidade, a resistência e a força de mães que mantêm suas famílias unidas nas circunstâncias mais difíceis". Ou seja, são as mães que tentam unir a família que a guerra vem separar. As mulheres são "verdadeiras heroínas", "elas garantem que a chama da esperança nunca se apagará". Tamanho clamor por exaltar a esperança das mulheres refugiadas por um futuro melhor e por recuperar a paz em suas vidas, transfere toda a nossa responsabilidade pelo futuro dos refugiados para elas. Isto nos redime e as transforma em verdadeiras heroínas.

Sabemos que o ACNUR oferece proteção particular a crianças, mulheres chefes de família e idosos, pois os reconhecem como um grupo em situação de extrema vulnerabilidade. Mas a preferência em expor imagens de mulheres a homens é curiosa. Se nos concentrarmos nos dados dos africanos - o maior grupo de refugiados em São Paulo - descobriremos que $77 \%$ desses refugiados são homens. Aliás, homens jovens e adultos, cuja média de idade varia entre 18 e 45 anos (CÁRITAS DE SÃO PAULO, 2007). Não é tão simples para as mulheres escaparem da zona de conflito e chegarem ao Brasil, um país distante e desconhecido.

Talvez, a presença de crianças e mães de família mobilize a sensibilidade do espectador, que passa a encarar o refugiado como uma vítima da guerra que precisa de contribuição financeira para receber ajuda humanitária. Mas isto é suficiente para suscitar sua elaboração crítica sobre as causas políticas do horror?

Quanto à exposição de refugiados de diversos continentes, os folhetos formam uma composição de fotografias com refugiados da África, América Latina, Ásia e Europa. Os fugitivos aparecem, por meio de trajes étnicos, folclóricos ou religiosos de seus locais de origem (Fig. 4). Temos, assim, africanas com suas roupas multicoloridas; mulheres muçulmanas do Oriente Médio completamente cobertas. Cada região é aqui representada em sua diversidade étnico-cultural. Apaga-se a história específica de suas guerras que condiciona as levas de refugiados para outros países.

Quanto aos cenários do refúgio, é possível ver realidades diversas do nosso país, como um lugar em ruínas por causa da guerra e muçulmanos do Oriente Médio em fuga sobre um caminhão. Além disso, temos acesso à imagem de uma forma de acolhida, que não encontramos no Brasil: o campo de refugiados (Fig. 5). 
Nos tempos atuais, $1 / 3$ dos refugiados residem em campos (UNHCR, 2011). Trata-se de uma acolhida em espaços de isolamento, situados à margem e afastados dos locais de vida comuns. Ali, a intervenção humanitária encarregase das vítimas, instaurando os cuidados e o controle (AGIER, 2006). Já o Brasil procura integrar os refugiados e receber os reassentados no seio da vida social?

Os folhetos mostram, ainda, a imagem de desolamento de uma menina num cenário em que africanos fogem a pé. Esta imagem cede lugar à cena de embarque de refugiados num navio, até encontrarmos uma mulher africana fazendo compras de mercado no cotidiano do novo lugar.

Estes cenários são acompanhados por palavras: “Ontem: Guerra. Opressão. Terror. Fuga. Fome. Hoje: Comida. Abrigo. Proteção. Assistência. Amanhã: Um novo começo. Um novo lar. Uma nova esperança." Tudo se passa como se o tempo transcorresse em progressão contínua. $O$ medo parece querer se referir ao passado vivido pelo refugiado e a esperança, ao futuro. $O$ passado, o presente e o futuro são ilustrados por fotos, que representam esta concepção de um tempo que progride e evolui, conforme as diferentes etapas no acolhimento aos refugiados. Porém, o apelo excessivo à palavra esperança talvez aponte para a ausência desse sentimento entre os refugiados e no meio de nós.

Verdade que não confinamos os refugiados em campos, como é frequente em muitos países africanos, contudo, a acolhida por nós oferecida é pouco capaz de intervir com eficácia nesta condição de tamanha vulnerabilidade.

Podemos ter uma dimensão da vulnerabilidade sofrida pelos refugiados ao ler o primeiro conjunto de propostas de políticas públicas que a Cáritas Arquidiocesana de São Paulo entregou ao Comitê Estadual para os Refugiados de São Paulo no dia de sua criação, em abril de 2008. Inclui a definição de um hospital de referência, a criação de um centro de acolhida aos recém-chegados, a construção de moradias provisórias, cotas nos programas de moradia popular, ajuda na revalidação de documentos universitários dos países de origem, criação de vagas nas universidades públicas, ajuda para obtenção de emprego, entre outras.

Apesar de os folhetos serem uma publicação da Cáritas de São Paulo, podemos supor que a maioria das fotos não foram feitas no Brasil, mas retiradas do arquivo internacional do ACNUR. Identificamos certa disparidade entre as fotografias e o conteúdo ali expresso nos folhetos: as imagens mostram campos de refúgio e embarque de refugiados num navio, enquanto o texto trata da acolhida no Brasil. Mas expor a condição dos refugiados no mundo não auxilia para o esclarecimento sobre a situação específica do nosso país.

$* * *$

Deslocando nosso olhar do conteúdo para a forma das fotografias, vemos imagens coloridas e iluminadas. O que mais nos chamou atenção encontra-se no aspecto virtuoso das fotografias. Os rostos estão enquadrados em close, quase não é possível observar o entorno. Não há uma única imagem distorcida, tremida ou fora de foco. 
Um abismo se compararmos com as fotografias de "Images malgré tout", em que Georges Didi-Huberman (2001) nos mostra como os judeus de Auschwitz, responsáveis pela câmara de gás e pelos crematórios para o extermínio em massa dos outros judeus, puderam deixar um testemunho desse horror em imagens. Em 1944, fotografaram clandestinamente o extermínio de vinte e quatro mil judeus húngaros, queimados vivos nos crematórios. $\mathrm{O}$ gás Zyklon $\mathrm{B}$ havia acabado. O campo de extermínio precisava ser esvaziado, com a chegada em massa de comboios com milhares de judeus. Era uma forma de arrancar uma imagem ao indescritível. São fotografias não enquadradas, pois esses prisioneiros temiam a morte. Márcio Seligmann-Silva, no "I Seminário Psicologia e Violência: ensino e pesquisa" 8 , considerou essas imagens "verdadeiros testemunhos".

Portanto, a forma das fotografias de refugiados mostra a beleza de suas cores e luzes, turvando nossa percepção sobre a condição de horror a que seus "modelos" estão expostos, pois em nada recordam ou em nenhum elemento ampliam nossa visão para a história dos refugiados.

\section{Considerações Finais}

Como pudemos ver, as fotografias apresentadas seguem o princípio estético da estilização: suas cores são vivas, são iluminadas, as pessoas sorriem para o fotógrafo e para seus espectadores e estão em close, talvez tentando denotar uma aproximação conosco. Mas, como será que a Cáritas de São Paulo representa em imagens suas diferentes perspectivas sobre o refugiado? Através da perspectiva religiosa, "a triste história de multidões obrigadas a sair de sua pátria" é retratada por meio de um cenário em ruínas e povos em fuga. Apesar de a solidariedade católica ter interesse na ação assistencial, sua interpretação a-histórica do refúgio não ajuda a nos situar no tempo atual. Através da perspectiva do direito internacional, o refugiado é apresentado em trajes típicos de seu local de origem e reduzido a um exemplo representativo de sua raça, religião, nacionalidade ou grupo social. Trata-se de uma vítima de perseguição, com direito de receber proteção jurídica.

Pensando as fotografias como possíveis obras de arte que testemunham o horror, poderíamos dizer que se traem no exato momento em que são apresentadas. Traem a verdade do trauma que essas pessoas carregam, escondem sua terrível origem, aquela que as expulsaram de seus países. Talvez não contribuam para esclarecer sobre seus passados e assim também não produzem a experiência de crise, como quer Felman, naqueles que são seus espectadores.

Talvez, tenhamos uma responsabilidade urgente, que é uma relação ética com a realidade. Neste caso, as fotos poderiam nos acordar para a realidade dos refugiados que estão acolhidos no Brasil e, particularmente, em São Paulo. No entanto, suas características não trazem muitas contribuições para pensarmos nem no passado e nem em seu futuro. Na medida em que não refletem sobre o horror, produzem condições para que o mesmo continue se reproduzindo, como pensou Adorno. 
Existe outro fator interessante: os fotógrafos, provavelmente não passaram pelos traumas de seus "modelos", e nem nós, que estamos aqui como espectadores, vivemos em nossa pele as dificuldades de uma guerra civil. A partir disso podemos falar que houve um testemunho? Se pensarmos que os fotografados tinham a intenção de mostrar algo, talvez poderíamos responder que sim. No entanto, o ato de testemunhar é solitário, quem testemunha passa por uma designação própria, não há meios de ser representado por outrem. Desse modo, levantamos a seguinte questão: Como seriam as fotos que os refugiados divulgariam de si mesmos?

Em 2006, o SESC Carmo (Serviço Social do Comércio) exibiu a mostra fotográfica, "Expressões do Refúgio", com imagens da cidade registradas pelos próprios refugiados. Vemos lado a lado a cidade do progresso, a cidade decadente e a cidade da memória. De um lado, prédios comerciais envidraçados e prédios residenciais confortáveis de varandas floridas. De outro, pequenos estabelecimentos comerciais e cortiços em prédios decaídos do centro. E, também, antigas construções do centro velho, como o viaduto do chá. Um refugiado fotografou a Igreja Maravilhas de Jesus Oração para Todos. Uma placa pendurada na porta da igreja informava os fiéis do plantão diário de oração, que oferecia cura divina e libertação. Mas o cartaz, colado no poste na rua da igreja, lembrava que o 1 o de maio era dia de luta (do trabalhador). Os retratos não mostravam os rostos dos refugiados, muito frequentes nos folhetos da Cáritas de São Paulo, mas os habitantes da cidade. Menino cantando em rua do centro, jovem vendendo biju no farol, morador de rua dormindo à luz do dia sob um guarda-sol na Praça da Sé. Os pobres da cidade chamaram a atenção dos refugiados. Mas não foram esquecidos os locais de cultura e lazer como o MASP (Museu de Arte de São Paulo), o Museu do Ipiranga (Museu Paulista da USP) e o Lago do Ibirapuera. Outro refugiado fotografou um artista de rua, no vão livre do MASP: um palhaço triste, com os pés acorrentados a caixas de remédios de tarja preta. Talvez, a cidade que oferece acolhida aos refugiados não seja, apenas, o lugar do futuro, enquanto progresso. Pois, também, é o lugar do presente decaído. Mas pode, ainda, remeter ao lugar do passado, com as marcas de sua memória.

É espantoso verificar que os próprios refugiados querem apagar o passado imerso no horror que motivou a fuga de seus países de origem. Alguns refugiados preferem evitar que as lembranças inundem seu cotidiano, para se manterem vivos. "É como uma mãe que perdeu a única filha. Até o último dia de sua vida, a mãe vai se lembrar. Porém, se ela não conseguir esquecer, morre de tristeza", diz um angolano. Outros refugiados constroem relatos "desafetados", como se a experiência vivida não fosse real. Falam de casas incendiadas e parentes mortos, como se eles mesmos não tivessem passado por isto (OLIVEIRA, 2011, p. 9-12). Ao invés de criticarem e denunciarem o mal humano, por um lado os refugiados querem esquecer o passado traumático e, por outro, a Cáritas de São Paulo transforma os refugiados em vítimas 
da guerra e embeleza suas fotografias para que tenhamos compaixão. Tudo isto não impede que se pare com o horror e não contribui para evitar que o sofrimento se repita.

\section{Notas}

1 - Este trabalho teve início na disciplina "Sujeito, Política e Psicanálise" do Prof. Paulo César Endo, através do Programa de Aperfeiçoamento ao Ensino (PAE) no segundo semestre de 2008. Uma versão deste texto foi apresentada no XV Encontro Nacional da Associação Brasileira de Psicologia Social, que ocorreu em Maceió em novembro de 2009.

2 - Destes 10,55 milhões são refugiados, que fugiram de seu país de origem, e 14,7 milhões são deslocados internos, forçados a se deslocar dentro do próprio país. A agência da ONU para Refugiados sugere ainda que existam, ao redor do mundo neste momento, 43,7 milhões de pessoas forçadas a se deslocar. (Isto inclui 15,4 milhões de refugiados, dentre eles 4,82 milhões de palestinos sob a responsabilidade da United Nations Relief and Works Agency for Palestine Refugees in the Near East (UNRWA), e 27,5 milhões de deslocados internos.) Portanto, apenas uma parte delas se encontra sob a responsabilidade da ONU. Outras, entretanto, caíram mesmo fora das estatísticas.

3 - Devemos a compreensão sobre o abalo da razão e da linguagem ao ensaio de Jeanne Marie Gagnebin "Após Auschwitz" in Lembrar escrever esquecer. São Paulo: Editora 34, 2006.

4 - Devemos a compreensão sobre a reflexão ética em Adorno ao ensaio de Jeanne Marie Gagnebin "Sobre as relações entre ética e estética no pensamento de Adorno" in Lembrar escrever esquecer. São Paulo: Editora 34, 2006.

5 - A lei 9.474/97 também criou o Comitê Nacional para os Refugiados (CONARE), presidido pelo Ministério Público e responsável por analisar o pedido e declarar o reconhecimento da condição de refugiado, decidir a cessação e determinar a perda da condição de refugiado; bem como orientar e coordenar as ações de proteção, assistência e apoio jurídico aos refugiados.

6 - Agradecemos ao ACNUR Brasil por autorizar a divulgação das fotografias dos refugiados. Os folhetos não informam quem são os fotógrafos, responsáveis pela autoria das imagens, tão pouco quais são os locais de origem e acolhida dos refugiados.

7 - Dos 4.401 refugiados que nosso país abriga, 430 são reassentados (CONARE, 2011). A maior parte dos reassentados que recebemos são colombianos, que tiveram dificuldades de integração no Equador e Costa Rica. A integração local e o reassentamento formam, com a repatriação voluntária, as "soluções duradouras" que o ACNUR busca para os refugiados. A repatriação é o retorno do refugiado, com segurança, para seu país de origem. A integração busca facilitar a inserção do refugiado no país de refúgio. $O$ reassentamento em outro país ocorre quando o refugiado não pôde permanecer no primeiro país de acolhida, por problemas de segurança ou integração, nem voltar ao seu país de origem.

8 - O "I Seminário Psicologia e Violência: Ensino e Pesquisa" ocorreu entre 16 e 17 de abril de 2009, no Instituto de Psicologia da USP.

9 - As fotografias foram cedidas à Cáritas Arquidiocesana de São Paulo.

\section{Referências}

ADORNO, T. Educação após Auschwitz. In: Educação e Emancipação. São Paulo: Paz e Terra, 2003

AGIER, M. Refugiados diante da nova ordem mundial. In: Tempo Social, v.18, no 2, 2006, p. 197-215.

ANDRADE, J. H. F. A proteção internacional dos refugiados no limiar do século XXI. In: Travessia, ano IX, no 25, maio-agosto, 1996, p. 39-42. 
COLEÇÃO FOLHA GRANDES FOTÓGRAFOS. Refugiados. Sebastião Salgado, Robert Capa, John vink, Larry Towell. Editorial Sol90 Ltda, 2009.

DIDI-HUBERMAN, G. Images malgré tout. In: CHÉROUX, Clément (org.), Mémoire des Camps. Photographies des Camps de Concentration et d'Extermination nazis (1933-1999). Paris: Marval, 2001.

FELMAN, S. Educação e crise ou as vicissitudes do ensinar. In: NESTROVSKI, A. e SELIGMANNSILVA, M.(org.). Catástrofe e Representação. São Paulo: Escuta, 2000.

FOLHETOS DA CÁRITAS Arquiodiocesana de São Paulo.

GAGNEBIN, J. M. Após Auschwitz. In: Lembrar escrever esquecer. São Paulo: Editora 34, 2006.

GAGNEBIN, J. M. Sobre as relações entre ética e estética no pensamento de Adorno. In: Lembrar escrever esquecer. São Paulo: Editora 34, 2006.

KURZ, R. Barbárie, migração e guerras de ordenamento mundial. Para uma caracterização da situação contemporânea da sociedade mundial. 2005. Disponível em: <http://obeco. planetaclix.pt>. Acesso em: 10 jun. 2010

OLIVEIRA, T. B. O esquecimento do passado por refugiados africanos. Dissertação (Mestrado em Psicologia Social). Instituto de Psicologia da Universidade de São Paulo, 2011.

SONTAG, S. Diante da dor dos outros. São Paulo: Companhia das Letras, 2003.

UNHCR. 2010 Global Trends: Refugees, Asylum-seekers, Returnees, Internally Displaced and Stateless Persons. Disponível em: www.unhcr.org/statistics. Acesso em: 25 jun. 2011.

\title{
RESUMO
}

Partindo das fotografias de refugiados, contidas nos folhetos da Cáritas Arquidiocesana de São Paulo, buscamos verificar se as imagens possibilitam uma experiência de crise que possa testemunhar sobre o passado imerso no trauma dos refugiados no Brasil. Analisamos o conteúdo e a forma das fotografias, destacando os retratos dos refugiados de diferentes idades, ambos os sexos e diversas regiões do mundo, bem como os cenários do refúgio. Descobrimos que as imagens seguem o princípio estético da estilização e não impedem que o horror se repita.

Palavras-chave: refugiados; fotografias; trauma e testemunho.

\begin{abstract}
Based on photographs of refugees included in the pamphlets of Cáritas Arquidiocesana de São Paulo, we intent to verify whether the images promote an experience of crisis which may testify to the past immerse in the trauma of the refugees in Brazil. We analyze the content and the shape of these photographs, showing up the portraits of the refugees of different ages, both sexes and different regions of the world, as well as the sceneries of the refuge. We discovered that the images follow the aesthetic principle of stylization and do not avoid that the horror repeats.
\end{abstract}

Keywords: refugees; photographs; trauma and testimony. 